\title{
A strategy to obtain recombinant cell lines with high expression levels. Lentiviral vector-mediated transgenesis
}

\author{
Claudio Prieto*, Diego Fontana, Marina Etcheverrigaray, Ricardo Kratje \\ From 22nd European Society for Animal Cell Technology (ESACT) Meeting on Cell Based Technologies \\ Vienna, Austria. 15-18 May 2011
}

\section{Background}

The primary goal of any recombinant protein production is to achieve successful gene transfer and expression in a target cell. There are two general categories of delivery vehicles/vectors employed in protein expression protocols. The first category includes the non-viral vectors, ranging from direct injection of DNA to complexing DNA with cationc lipds, polylysine, etc. The second category comprises DNA and RNA viral vectors.

Viruses have evolved specific mechanism to deliver their genetic material to target cell nuclei. Virus members of family Retroviridae, e.g. retroviruses and lentiviruses, are among the most widely used viral vectors. The use of lentiviral vectors has been increasing because the vector system has attractive features. Lentiviruses have an advantage over retroviruses in that they can infect both dividing and non-dividing cells and therefore have attracted much attention regarding the potential as vectors for gene delivery/therapy. Once integrated into the genome, recombinant cell lines are selected using different selection mechanisms.

\section{Results}

Lentivirus particles were produced by simultaneous cotransfection of HEK 293T cells with four plasmids. The packaging construct (pMDLg/pRRE) [1], the VSV-Gexpressing construct (pMD.G) [2], the Rev-expressing construct (pRSV-Rev) [1], and the self-inactivating (SIN) lentiviral vector construct containing the green fluorescent protein (GFP) reporter gene (pLV-PLK-eGFP). The

\footnotetext{
* Correspondence: cprieto@fbcb.unl.edu.ar

Cell Culture Laboratory, School of Biochemistry and Biological Sciences, Universidad Nacional del Litoral. Ciudad Universitaria - C.C.242 - (S3000ZAA) Santa Fe, Provincia de Santa Fe, Argentina

Full list of author information is available at the end of the article
}

medium containing lentiviral particles was collected 48 $\mathrm{h}$ after transfection, clarified by centrifugation $10 \mathrm{~min}$ at $2000 \mathrm{rpm}$ and then stored at $-80^{\circ} \mathrm{C}$. To determine viral titers, HEK 293T cells were seeded at $3 \times 10^{4} \mathrm{cell} / \mathrm{ml}$ in 6 -well plates and mantained for $18 \mathrm{~h}$. The supernatant was replaced with $1 \mathrm{ml}$ of diluted lentiviral particles supernatant containing pLV-PLK-GFP, followed by incubation overnight. Then, the supernatants were replaced with fresh medium. The cells were analized by flow cytometry and the percentage of GFP positive cells were counted $96 \mathrm{~h}$ post transduction. Titer was calculated from the dilutions at which the percentage of eGFPpositive cells fall within the range of $1-30 \%$ using the following formula [3,4]: Titer $(\mathrm{TU} / \mathrm{ml})=[\mathrm{F} \times \mathrm{C} / \mathrm{V}] \times \mathrm{D}$; where $\mathrm{TU} / \mathrm{ml}$ : transduction units $/ \mathrm{ml}$, F: frequency of GFP-positive cells, C: total number of cells in the well at the time of transduction, $\mathrm{V}$ : volume of inoculum in $\mathrm{ml}$, and $\mathrm{D}$ : lentivirus dilution.

The viral titer was as high as $4.4 \times 10^{8} \mathrm{TU} / \mathrm{ml}$.

After that, HEK 293T cells were seeded at a density of $6 \times 10^{4} \mathrm{cell} / \mathrm{ml}$ in 6 -well plates and after $24 \mathrm{~h}$ the supernatant was replaced by $1 \mathrm{ml}$ medium containing lentiviral vectors. $96 \mathrm{~h}$ post-transduction the cells were analyzed by flow cytometry $(t=0)$; then, the cells were incubated with the puromycin selection agent to obtain stable recombinant cell lines. Two protocols were employed: A-) Single-step selection protocol: the cells were incubated with $1,5,10,50,100,150,200$ and 250 $\mu \mathrm{g} / \mathrm{ml}$ of puromycin in different plates, and B-) Multistep gradual selection protocol: the cells were incubated from 1 up to $250 \mu \mathrm{g} / \mathrm{ml}$ of puromycin, but the selection agent was gradually changed each 7 days on the same plates (Table 1).

Once the cells were resistant to different concentrations of puromycin, recombinant cell lines were 
Table 1 eGFP expression level of different recombinant cell lines according to puromycin concentration

\begin{tabular}{|c|c|c|c|}
\hline Recombinant cell line & Puromycyn $(\mu \mathrm{g} / \mathrm{ml})$ & Single-step selection protocol & Multistep gradual selection protocol \\
\hline & & \multicolumn{2}{|c|}{ Fold increase eGFP expression (X-mean) } \\
\hline $\mathrm{CL} 1$ & 1 & 1.0 & 1.0 \\
\hline CL5 & 5 & 2.0 & 2.0 \\
\hline CL10 & 10 & 2.0 & 2.0 \\
\hline CL50 & 50 & 2.0 & 2.0 \\
\hline CL100 & 100 & $\mathrm{nv}$ & 4.5 \\
\hline CL150 & 150 & $\mathrm{nv}$ & 4.5 \\
\hline CL200 & 200 & $\mathrm{nv}$ & 6.0 \\
\hline CL250 & 250 & nv & nv \\
\hline
\end{tabular}

nv: non viable cells

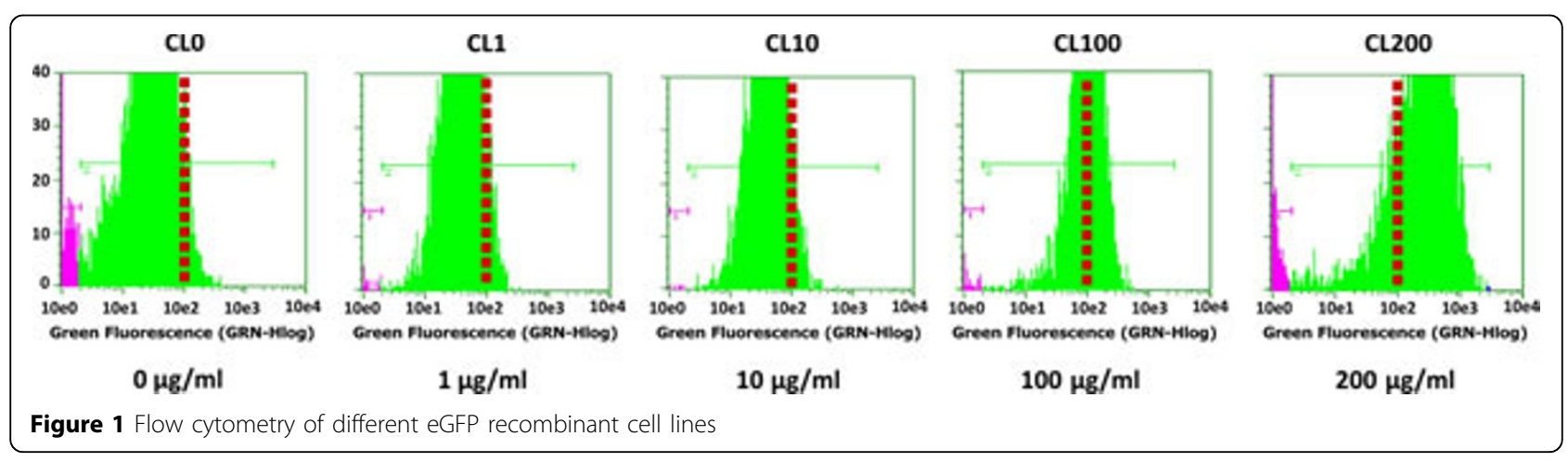

cryopreserved and analyzed by flow cytometry to compare the expression of eGFP ( $x$-mean). Recombinant cell lines showed different eGFP expression levels according to puromycin concentration. The cell line CL200 showed the highest eGFP expression level (Figure 1).

\section{Conclusions}

Employing the gradual selection protocol, it was possible to maintain the cells in culture condition up to $200 \mu \mathrm{g} /$ $\mathrm{ml}$ puromycin and achieve higher expression levels of the reporter gene, between 2 and 6 times depending on puromycin concentration. Contrarily, in the single-step selection protocol cells cultures were resistant only up to $50 \mu \mathrm{g} / \mathrm{ml}$ and expression levels of eGFP were lower. Simultaneously, resistant cell lines were cloned by limit dilution methods and the resulting cell clones were also analyzed by flow cytometry. The eGFP expression of each clone was consistent with the ones observed in the respective resistant cell lines (data not shown). Therefore, with this strategy of recombinant cell line selection, it was possible to obtain high eGFP producing stable cell clones without the use of any gene amplification system.

Published: 22 November 2011

\section{References}

1. Dull T, Zufferey R, Kelly M, Mandel RJ, Nguyen M, Trono D, Naldini L: A third-generation lentivirus vector with a conditional packaging system. $J$ Virol 1998, 72:8463-8471.

2. Naldini L, Blomer U, Gallay P, Ory D, Mulligan R, Gage FH, Verma IM, Trono D: In vivo gene delivery and stable transduction of nondividing cells by a lentiviral vector. Science 1996, 272:263-267.

3. White SM, Renda M, Nam NY, Klimatcheva E, Zhu Y, Fisk J, Halterman M, Rimel BJ, Federoff $H$, Pandya S, et al: Lentivirus vectors using human and simian immunodeficiency virus elements. J Virol 1999, 73:2832-2840.

4. Sastry L, Johnson T, Hobson MJ, Smucker B, Cornetta K: Titering lentiviral vectors: comparison of DNA, RNA and marker expression methods. Gene Ther 2002, 9:1155-1162.

doi:10.1186/1753-6561-5-S8-P7

Cite this article as: Prieto et al:: A strategy to obtain recombinant cell lines with high expression levels. Lentiviral vector-mediated transgenesis. BMC Proceedings 2011 5(Suppl 8):P7.

Submit your next manuscript to BioMed Central and take full advantage of:

- Convenient online submission

- Thorough peer review

- No space constraints or color figure charges

- Immediate publication on acceptance

- Inclusion in PubMed, CAS, Scopus and Google Scholar

- Research which is freely available for redistribution 